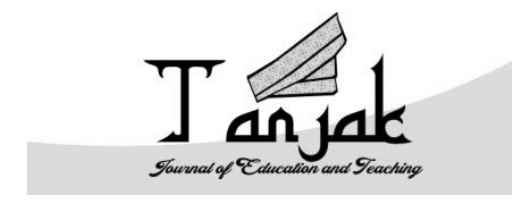

Tanjak: Journal of Education and Teaching

ISSN 2716-4098 (P) 2720-8966 (O)

Volume 1 Nomor 1, 2020

\title{
DINAMIKA PERTUMBUHAN PENDIDIKAN ISLAM PERIODE PERTENGAHAN
}

(Setelah Jatuhnya Baghdad, Kerajaan Mughal Di India, Kerajaan Safawi Di Persia, Dan

Kerajaan Usmani Di Turki)

\author{
Sulistiyowati Gandariyah Afkari
}

sulistiyowati@stainkepri.ac.id

STAIN Sultan Abdurrahman, Bintan, Kepulauan Riau, 29135, Indonesia

DOI: https://doi.org/10.35961/tanjak. v1i1.82

\begin{abstract}
Abstrak
Praktik pendidikan dan kehidupan intelektual pada masa Dinasti Safawi ini secara keseluruhan diarahkan untuk memperkokoh doktrin paham Syi'ah. Pada satu sisi paham Syi'ah demikian keras diinjeksikan pada seluruh lapisan dan wilayah kesadaran intelek rakyat demi memperkokoh posisi kekuasaan para Syah. Dan pada sisi lain penguatan birokrasi hingga penggunaan kekerasan militeristis dijadikan alasan untuk memperkuat keyakinan ajaran syiah. Adapun system dan praktek pendidikan pada masa Dinasti Safawi ini, semata mata didominasi oleh tiga jenis pendidikan: pertama pendidikan indoktrinatif sebagai kurikulum inti dalam seluruh pusat pendidikan untuk memantapkan paham Syi'ah demi terwujudnya patriotisme masyarakat untuk mengabdi kepada mazhab keagamaan.Dan kedua pendidikan estetika dengan penekanannya pada seni karya yang dihadapkan mampu mendukung sector industry dan perdagangan Dinasti Safawi. Ketiga pendidikan militer memperkuat armada perang
\end{abstract}

Kata Kunci : Pendidikan Islam, Abad Pertengahan 


\begin{abstract}
The practice of education and intellectual life during the Safavid era as a whole was directed to strengthen the doctrine of Shi'ism. On the one hand, Shi'ism is so strongly injected into all layers and areas of people's intellectual consciousness in order to strengthen the position of power of the Shah. And on the other hand the strengthening of the bureaucracy to the use of militaristic violence is used as an excuse to strengthen the beliefs of Shia. The educational system and practice during the Safavid era was solely dominated by three types of education: firstly indoctrinative education as a core curriculum in all educational centers to establish Shi'ism for the realization of community patriotism to serve religious schools. And secondly aesthetic education with the emphasis is on the art of work which is faced with being able to support the Safavid industry and trade sectors. Third military education strengthens the fleet of war.
\end{abstract}

Keywords: Islamic Education, Middle Ages

\title{
Pendahuluan
}

Pendidikan dan politik adalah dua elemen penting dalam sistem sosial sebuah negara, baik negara maju maupun negara berkembang. Keduanya sering dilihat sebagai bagian-bagian yang terpisah, yang satu sama lain tidak memiliki hubungan apa-apa, padahal keduanya bahu membahu dalam proses pembentukan karakteristik masyarakat disuatu negara. Lebih dari itu, keduanya sama lain saling menunjang dan saling mengisi.

Lembaga-lembaga dan proses pendidikan berperan penting dalam membentuk perilaku politik masyarakat dinegara tersebut. Begitu juga sebaliknya, lembaga-lembaga dan proses politik di suatu negara membawa dampak besar pada karakteristik pendidikan di negara itu. Ada hubungan erat dan dinamis antara pendidikan dan politik di setiap negara. Hubungan tersebut adalah realitas empiris yang telah terjadi sejak awal perkembangan peradaban manusia dan menjadi para ilmuwan.(Sirozi,2005:1)

Untuk itu pada uraian berikut penulis mengemukakan beberapa pokok permasalahan yaitu : Bagaimana dinamika pertumbuhan pendidikan Islam priode pertengahan pada :

1. Setelah jatuhnya Baghdad,

2. Masa kerajaan Mughal di india,

3. Masa kerajaan Safawi di persia,

4. Masa kerajaan Usmani di turki

\section{PEMBAHASAN}

\section{SETELAH JATUHNYA BAGHDAD}

Masa Mongol dalam sejarah kebudayaan Islam mulai setelah jatuhnya Baghdad pada tahun $656 \mathrm{H} /$ 1258 M, sampai masuknya tentara Usmani ke Mesir, kemudian menguasai Afrika utara, jazirah Arab, Siria pada tahun 1517, dibawah pimpinan sultan Salim.

Kekuasaan Mongol membujur dari perbatasan India di sebelah timur sampai ke perbatasan siria disebelah barat,di celah-celah itu pernah keturunan Persi dan Arab menguasai Persia dan Irak dalam waktu singkat. Di daerah kekuasaan Mungol ini berdiri daulah Elkhaniyah yang berkuasa di Irak dan Persi, yang kemudian digantikan oleh daulah Timuriyah. Daulah Syagtaniyah yang menguasai Turkistan dan Afghanistan, kemudian direbut oleh daulah Timuriyah. (Sunanto, 2003:193) 
Pada masa itu Dunia Islam dikuasai keturunan Jenghis Khan terpecah belah, saling serang menyerang satu sama lain sehingga tidak ada sebuah kerajaan besar menjadi tumpuan harapan umat Islam dan sempat membangun. Dengan demikian masa Mongol ini merupakan masa perpecahan yang sangat parah di dalam sejarah kebudayaan Islam. ( Sunanto, 2003:194)

Kegiatan Ilmu yang pada masa Abbasiah berpusat di kota-kota Baghdad, Bukhara, Naisabur, Ray, cordova, sevilla, ketika kota-kota tersebut hancur, maka kegiatan ilmu berpindah ke kota-kota Kairo, Iskandariyah, Usyuth, Faiyun, Damaskus, Hims, Halb dan lain-lain kota di Mesir dan di Syam.

Dalam masa ini, mulai matang ilmu umron ( sosiologi ) dan filsafat Tarikh (philosophy of history ) dengan munculnya Muqaddimah Ibnu Khaldun sebagai kitab pertama dalam bidang ini. Juga mulai disempurnakan penyusunan ilmu politik, ilmu tata usaha, ilmu peperangan, ilmu kritik sejarah.

Pada zaman ini banyak perpustakaan besar yang musnah bersama segala kitabnya karena terbakar atau tenggelam ditengah-tengah yang kacau waktu penaklukan Mongol di Timur, dan penaklukan Spanyol di Barat, atau pemusnahan kitab-kitab dan perpustakaan sebagai akibat terjadinya pertentangan sengit antara firqah-firqah agama, atau karena rusaknya kertas dan mengaburnya tinta akibat lapuk dimakan usia. ( Sunanto, 2003: 195)

Pada masa ini sekolah-sekolah yang teratur tumbuh subur, terutama di Mesir dan Syam, dan yang menjadi pusatnya adalah Kairo dan Damaskus. Pembangun sekolah pertama adalah Sultan Nuruddin Zanky yang kemudian diikuti oleh para Raja dan Sultan sesudahnya. Berdirilah berbagai corak sekolah baik karena perbedaan Mazhab ataupun karena kekhususan Ilmu. Ada sekolah untuk ilmu tafsir dan Hadis, ada sekolah untuk Fiqh berbagai mazhab, ada sekolah untuk ilmu Thib dan filsafat, ada sekolah untuk ilmu riyad-hiya'at ( ilmu pasti, ilmu musik dan ilmu eksakta lainnya ). Dari sekolah ini keluarlah para ulama dan sarjana yang jumlahnya banyak. Kecuali banyaknya sekolah, zaman ini istimewa dengan lahirnya mausu'at dan majmu'at ( buku kumpulan berbagai ilmu dan masalah, kira-kira seperti Encyclopedia). ( Sunanto, $2003: 196$ )

Ketika kaum Muslimin terendam darah kesedihan, serangan Mongol sedang menghebat, pembunuhan. Penghancuran, perampokan dan pemusnahan merajalela, masih juga umat Islam dapat berfikir, menciptakan sesuatu yang besar dan melahirkan ilmuwan Internasional, walaupun jumlahnya sedikit antara lain :

a. Ibnu Taimiyah, lahir tahun 661 H/1263 M, di Harran. Beliau adalah perintis dan pejuang bidang agama.

b. Nashir ad-Din Tusi, nama lengkapnya adalah Abu Jafar Muhammad ibn Muhammad ibn Hasan Nasir ad-Din Tusi,wafat tahun 676 H/ 1274 M. Nasir ad-Din Tusi mendirikan sebuah observatorium di Maragha, sebuah tempat yang terletak di Asia kecil. Dari Obesrvatorium inilah ia dapat memperbaharui ilmu Bintang. Diperbuatnya jadwal perjalanan Bintang baru yang dinamai jadwal Elkhaniyah, sebagai penghormatan kepada raja Mongol yang memberi bantuan untuk mendidirikan observatorium ini. Nasir ad-Din Tusi sama saja mashurnya dalam bidang ilmu bintang dan ilmu ukur (geometri)

c. Ulugh Bek. Pada tahun 1437 umat Islam juga masih melahirkan seseorang yang menciptakan jadwal astronomi baru, jadwal itu diberi nama Ulugh Bek. Ulugh Bek adalah seorang cucu Timur Lenk dari keturunan Hulagodi samarkand,yang memerintah 1447 - 1452 M. dia memerintah tidak kejam sebagaimana nenek moyangnya ,bahkan beliau masyhur karena alimnya dalam bidang agama dan ahlinya sebagai seorang sarjana ilmu pasti. (Sunanto, 2003: 199-207) 


\section{KERAJAAN MUGHAL DI INDIA}

Dinasti Mughal, muncul pertama kali sebagai serangan sebuah bangsa di Asia Tengah terhadap India bagian Utara, dipimpin oleh Babur (1556-1605) dari klan Mongol, setelah mereka diusir dari Asia Tengah oleh Dinasti Safawi dan Uzbek. Ia mengklaim kepemimpinan karena menurutnya Ia merupakan keturunan Timur dan Jengis. Karena itulah, Dinasti Mogul mengangggap Afganistan dan tansoxania sebagai tanah air dinasti mereka.

Akbar (m.1556-1605), menaklukkan beberapa wilayah di barat, timur dan selatan, serta mengubah dinasti menjadi satu kekuatan dunia. Pada masa Autangzeb (1658-1707), kedaulatan mereka meluas hingga meliputi sebagian besar India, kecuali ujung selatan, dan menciptakan Negara India yang paling luas sejak raja Ashoka pada abad ketiga S.M Akbar bermaksud menciptakan sebuah kerajaan yang multi ajaran. Sejak pertengahan abad ke-17, Negara itu kembali menganut Sunnisme ortodoks. Dan kekuasaan mogul merosot drastic pada abad ke-18. ( Black, 2006: 433)

Pada masa Akbar, Akbar dipercaya dapat membangkitkan kesadaran spiritual orang lain. Landasan revolusi Akbar adalah perpaduan antara peran raja dan peran guru spiritual. Apa sesungguhnya yang mengubah susasana emosional dan membentuk solidaritas, serta kekuatan yang semakin meningkat bagi tahta Mongol adalah ideology sufistik tentang manusia sempurna. Akbar memberi status yang sama kepada umat Hindu dan Islam, bahkan Akbar melakukan upaya mendamaikan sekte-sekte dalam Islam.

Sebagai sebuah upaya untuk menggiring kedua komunitas itu agar memandang raja sebagai pemegang otoritas tertinggi dalam urusan agama, Akbar (1579) mengeluarkan "Dekrit Kesucian" ( Mazhar ). Dekrit ini menyatakan bahwa : Seandainya masa depan timbul suatu masalah agama, yang diperselisihkan oleh para Mujtahid, dan Yang Mulia ( Raja ), sesuai dengan nalarnya yang tajam dan kebijkasanaannya cenderung memilih demi kepentingan rakyat dan kebaikan pemerintahan, salah satu dari pendapat yang berselisih itu, maka ia harus mengeluarkan suatu perintah untuk mencapai tujuan yang dimaksud. Kami disini sepakat bahwa dekrit itu mengikat kita semua dan seluruh komunitas.

Akbar bersama guru spiritualnya Abu'l Fadl melangkah lebih jauh dan menyajikan tidak saja sebuah bentuk Islam yang diperbaharui, melainkan sebuah agama baru yang disebut "agama Tuhan ( Din Ilahi). Bagi mayoritas Muslim, ideologi Akbar tentu saja dianggap sebagai kemurtadan, bahkan Sekh Ahmad Sirhindi ( 1564 - 1624 ), seorang Naqsyabandi, sangat menentang ajaran Akbar dan mendesak masyarakat untuk mengamalkan nilai-nilai Islam dalam kehidupan publik. ( Black, 2006: 443-448)

Pelaksanaan Hukum Islam secara lebih ketat diterapkan pada masa kekuasaan Syah Jahan yang bergelar "pilar syariat, pendukung khalifah dan niyabat ( wakil Tuhan dimuka bumi, Khalifah Tuhandi dua dunia, dan mujaddid iru yang muncul per milinium. Ia melarang pembangunan tempat-tempat ibadah non Muslim. Black, 2006: 453)

Pada masa Akbar kemajuan ilmu pengetahuan tidak banyak mengalami kemajuan dibandingkan dengan kemajuannya di masa-masa sebelumnya. Yang lebih menonjol adalah kemajuan dalam bidang seni syair dan seni arsitektur. Penyair istana terkenal adalah Malik Muhammad jayazi, seorang satrawan Sufi yang menghasilkan karya besar bernama Padmavat. Ia merupakan karya Alegoris yang berisikan ajaran dan pesan kebajikan jiwa manusia. Abul fadl merupakan sejarawan terkenal dengan karyanya Akhbar namah dan Aini Akhbari yang menerangkan sejarah Mughal berdasarkan figur pemimpinnya. ( Ali, 2003: 537-538) 
Syah Jahan membangun Taj mahal untuk makam permaisuri yang sangat dicintainya. Bangunan ini menjadi kekaguman dunia sampai sekarang, termasuk salah satu dari tujuh keajaiban dunia, juga Membangun masjid Moti "masjid Mutiara di Agra, disamping Taj mahal, seluruhnya terbuat dari marmer dan dipahatkan ayat al-Qur'an didalamnya dengan mempergunakan marmer hitam.( Sunanto, 2003: 260)

Aurangzeb putera Syah jahan memerintah ( 1670-1707), Ia memulai jihad melawan para pemimpin Hindu dan memperluas kerajaan Mogul hingga ke India Selatan. Ia memperkenalkan kembali ortodoksi Sunni ke Masyarakat dan membangun suatu system hukum yang menyatu berdasarkan fkih mazhab Hanafi (sebuah kompilasi besar yang berisi ajaran-ajaran mazhab ini yang diberi nama Fatawa-i 'Alamgiri. ( Black, 2006:454)

Syah Waliyullah al-Dihlawi (Delhi 1703-1762 ), memperakarsai suatu pendekatan baru terhadap pemikiran sosial dan politik Islam, yang didasarkan atas pandangan orisional tentang evolusi sosial. Ia merupakan anggota tariqat Naqsyabandiyah, yang kemudian mengganti ayahnya sebagai kepala madrasah dan ke Mekkah berhaji dan belajar (1730-1732). Beliau mengembangkan dua perakarasa teoritis yang cukup penting. Pertama memperluas penggunaan Ijtihad (penetapan hukum melalui upaya rasional ). Pandangannya ini berkaitan dengan sebuah gagasan modern yang revolusioner, yang menyatakan bahwa syariat harus ditafsirkan dengan mempertimbangkan keadaan ketika ia diturunkan atau di formulasikan; dan bahwa syariat harus disesuaikan dengan kebutuhan dunia kekinian yang terus berubah. Gagasannya itu ditulis dalam Argumen Puncak. Allah (Hujjatullah aal-Balighah)

Kedua, Waliyullah ingin memadukan pendekatan ulama yang Fikih sentries dengan pendekatan sufi yang terlampau mistis, Dia menganjurkan untuk "menghapus semua system", dan memunculkan sebuah pendekatan baru yang didasarkan atas perinsip kesesuaian (Tathbiq). Ia mengatakan bahwa "Tuhan berkehendak agar kita menahan diri dari perselisihan dan sektarianisme. Kelihatannya bahwa pandangannya ini merupakan efek dari pendekatan sejarahnya yang revolusioner. Dalam mengkaji perbedaan doctrinal, ujar Waliyullah, orang harus mepertimbangkan bahwa semua perbedaan itu telah diadaptasikan dengan semangat zamannya masing-masing, bahkan keragaman ritual agama harus ditoleransi ( khusus bagi umat islam ). (Black, 2006:454-455)

Gagasan Waliyullah bahwa perkembangan syariat berbeda-beda sesuai dengan perbedaan waktu dikembangkan dalam konteks teori umum tentang perkembangan sosial. Menurutnya manusia mempunyai tiga karakter yang tidak dimiliki oleh makhluk lain yaitu (1) ia memiliki pandangan bersama ( al-Ra'y al-kulliy);(2) perasaan estetika dan;(3) Pada sekelompok orang “yang berakal dan bereksadaran "kemampuan untuk menciptakan dan memilih pendukung-pendukung peradaban (intifaqat).

Ada empat tahapan intifaqat. Tahapan pertama adalah peradaban yang meliputi bahasa, pertanian, peternakan, pembangunan, pakaian, pernikahan monogamy, dan peralatan. Tahapan ini dicapai oleh semua bangsa, termasuk komunitas terkebelakang dan masyarakat terpencil seperti penduduk yang tinggal di padang pasir, pegunungan dan daerah yang jauh dari wilayah yang hangat.

Intifaqat Kedua, adalah peradaban yang telah mencapai ilmu ( hikmah) untuk menguji dan memperhalus kepandaian manusia melalui pengujian yang benar dalam setiap bidang. Pada tahapan ini manusia akan memilih sikap yang jauh dari kejahatan dan dekat dengan kebaikan. Tahapan ini dicapai oleh penduduk yang menetap dan penduduk perkotaan yang berkembang di wilayah yang hangat, termasuk dalam tahapan ini adalah pengaturan runmah tangga, dan transaksi ekonomi yang muncul dari pembagian kerja yang diperlukan. 
Intifaqat ketiga dicapai oleh komunitas yang telah menguasai ilmu pemerintahan kota atau Negara ( madinah ) yaitu ilmu yang mengatur sebuah kelompok yang hidup berdekatan, berinteraksi satu sama lain dan tinggal dirumah-rumah terpisah. Oleh karena itu masyarakat membutuhkan sosok yang kuat dan berkuasa, seorang pemimpin (imam ) dalam pengertian yang sesungguhnya.

Intifaqat keempat terwujud ketika raja-raja dari Negara-negara semacam itu berselisih satu sama lain, untuk menyelesaikannya mereka terpaksa harus mengangkat seorang Khalifah ( Raja diraja) yang memiliki pasukan militer dan perlengkapan sempurna yang membuatnya kokoh, dan mustahil bagi siapa pun untuk menggoyangkan kekuasaannya. Contoh pemimpin yang termasuk kategori ini adalah Iskandar Agung dan Muhammad SAW. Walyullah melihat bahwa khalifah semacam ini tidak menguasai seluruh dunia, melainkan hanya sebagaian saja.

Berkat konsepnya tentang penggunaan ijtihad dan relativitas praktik agama, ia sangat layak disebut "pendiri modernisme dalam islam", Konsepnya tentang sifat manusia boleh jadi telah membuka jalan menuju reoreintasi pemikiran Islam, baik merespons rasionalisme Eropa atau bukan. Teorinya tentang khalifah "Jenderal" menyiapkan landasan untuk pemikiran politik abad ke-20. Dalam sebagian upaya sekularisasinya terhadap konsep kekhalifaan, dan kemudian konsep Negara Islam, sesungguhnya ia tampak lebih modernis ketimbang para pemikir Islam lainnya, namun ia mempertahankan pandangannya tentang kelompok elit intelektual. (Black, 2006:456-462)

\section{KERAJAAN SAFAWI DI PERSIA}

Nama Safawi diambil dari nama depan seorang pemimpin aliran keagamaan 9 tarekat ) yakni Sfi alDin Ishak al-Arabi ( 1252-1334 ) karena itulah tarekatnya dikenal dengan Safawiyyah. Terdapat dua versi mengenai asal usul Syekh Safi ini. Pendapat pertama mengatakan bahwa Safi keturunan Musa alKadzim (Imam ketujuh dalam aliran Syiah dua belas ), Ia dianggap masih keturunan Nabi Muhammad SAW dari Sitti Fatimah. Pendapat kedua mengatakan Safi adalah keturunan asli Iran dari suku Kurdi keturunan Darwisy yang berbahasa Azari (bahasa Turki) yang digunakan di Azerbaizan dan yang perlu dicatat dari pendapat kedua ini adalah ia seorang Sunni bermazhab Syaft'i. (Fauzan, 2005: 136)

Ketika pemimpin tarekat dipegang oleh Junaid ( 1447-1460), aliran keagamaan ini memperluas gerakannya ke wilayah politik, hingga muncul keinginan untuk mendirikan pemerintahan sendiri, dan setengah abad kemudian ternyata keinginan junaid dapat terwujud dengan berdirinya kerajaan Dinasti Safawi dibawah proklamtornya Syah Ismail. Sejak itu paham Syi'ah ( Syi'ah dua belas ) ditetapkan sebagai agama resmi Negara.

Sejak berdirinya imperium Syiah ini, Safawi melakukan ekspansi untuk menyatukan kembali beberapa wilayah Persia ke dalam kesatuan kerajaan Islam. Perluasan dan penyatuan kembali tersebut dapat dimaknai sebagai perwujudan motivasi keagamaan atau syiar Islam. Namun dengan melihat perkembangan lebih lanjut dari praktek pemerintahan yang dijalankan oleh Dinasti ini akan mengambil kesimpulan tersebut. Terdapat fakta-fakta sejarah yang mendorong untuk meragukan keikhlasan motivasi keagamaan yang mula pertama diniatkan oleh Junaid semasa Syi'ah dua belas ini masih sebagai tarekat keagamaan. Atau setidaknya tidak akan terlalu salah apabila niat awal pendirian suatu daulat/Negara dapat berubah menyesuaikan kecenderungan zaman dan atau interes pada masingmasing para pelaku di dalamnya.

Secara berurutan imperium Safawi diperintah oleh para raja yang selalu bergelar Syah, mereka adalah : Ismail I ( 15011524); Tahmasp I ( 1524-1576 ); Ismail II ( 1576-1577 ); Muhammad Syah ( 
1577-1587 ); Abbas I ( 1588-1628 ); Safi Mirza ( 1628-1642 ); Abbas II ( 1642-1667); Sulaiman ( $1667-$ 1694 ); Husain (1694-1722); Tahmasp II ( 1722-1732); dan Abbas III ( 1732-1736 ).

Ismail Syah pertama sekaligus Deklarator Safawi digambarkan bahwa Dia bukan sekadar sebagai seorang raja dan jenderal panglima perang melainkan sebagi seorang terpelajar yang sangat menyukai ilmu pengetahuan, bahkan memiliki kebiasaan menulis puisi dengan menggunakan bahasa Turki. (Fauzan, 2005: 136-139)

Pada periode Syah Abbas I merupakan puncak kejayaan Dinasti safawi. Sejarah mencatatnya sebagai bangkitnya kembali kejayaan lama Persia. Sikap Syah Abbas I terhapa pengembangan keilmuan dan pendidikan dapat dilihat dari fisik material, keberhasilannya ditunjukkan dengan dibangunnya 162 masjid dan 48 pusat pendidikan, versi lain menyebut 162 masjid dan 446 sekolah. (Lapidus, 2003: 453)

Catatan lain menunjukkan bahwa jumlah sekolah/perguruan tersebut sebagian didirikan atas inisiatif ( atau perintah ) para kerabat kerajaan. Beberapa diantaranya adalah Dilaram Khanum (nenek dari Syah Abbas II ) yang mendirikan madrasah "Nenek Kecil" ( small grandmother) pada tahun 16451646 dan madrasah "Nenek Besar" ( Large grandmother) pada tahun 1647-1648. Kedua madrasah ini diwakafkan sebagai dedikasinya pada dunia pendidikan. Terdapat pula putrid Syah Safi yakni Maryam Begun yang mendirikan madrasah pada tahun 1703-1704. Sahr Banu, adik perempuan Syah Husain mendirikan madrasah bagi para pangeran pada tahun 1694-1722.

Disamping didirikan oleh kerabat kerajaan, juga didirikan oleh para hartawan Dinasti Safawi, dua diantaranya adalah Zinat Begum, isteri seorang fisikawan Hakim al-Mulk Ardistani, mendirikan madrasah Nim Avard pada tahun 1705-1706. Izzat al-Nisa Khanum, putri pedagang dari Qum Mizra Khan juga isteri Mirza Muhammad Mandi yang mendirikan madrasah Mirza Husain pada tahun 16871688. (Fauzan, 2005:139-140)

Ilmu pengetahuan yang berkembang pada masa ini khusus pada bidang pemikiran Teosofi dan filsafat, bukan ilmu pengetahuan dalam pengertian sains secara umum. Pemikiran teosofis dan filsuf tersebut lebih ditujukan sebagai penyatuan antara sufisme Ghnostik dengan beberapa kepercayaan Syi'i. Proses penyatuan tersebut berlangsung dalam rentang abad 16 dan 17 tersebut.

Hal itu dapat dipahami manakala Syah Ismail pada mula pembentukan dinastinya, yang menjadikan teologi Syi'I sebagai teologi Negara. Dengan demikian pembangunan pusat-pusat pendidikan yang dilakukan tentu juga dalam tujuan yang sama, yakni pendidikan yang diarahkan sebagai penguatan akidah dan desiminasi Syi'ah khususnya Syi'ah dua belas.

Ismail menyadari bahwa pengikut alirannya merupakan golongan minoritas di lingkup wilayah daulah Islamiyah, Dia tidak segan-segan untuk mendatangkan (mengimpor) para sarjana dan ulama yang akan berperan sebagai guru/pendidik sekaligus propagandis dan penanam credo Syi'ah dua belas. Mereka dari wilayah-wilayah Syi'ah dari bagian selatan Lebanon, Ulama Syiah dari Syria, Bahrain, dan Arabia Utara. Untuk melengkapi system pendidikan Syi'ah dua belas ini, maka buku-buku referensi sebagai kurikulum sekolah juga dimpor dari berbagai daerah tersebut. Lengkaplah system pendidikan pada masa dinasti Safawi ini sebagai prototype system pendidikan Syi'ah. (Fauzan, 2005: 141-142)

Sultan terbesar, Abbas yang agung, naik tahta dalam usia 17 tahun dan memerintah dari tahun 1558-1620 M. Sultan Abbas memindahkan ibukota ke Isfahan yang dihiasi dengan istana-istana, masjidmasjid, jembatan dan taman bunga. Pada zamannya berkembanglah kebudayaan dan ilmu pengetahuan. Diantara ilmuan yang terkenal adalah Muhammad Baqir ibn Muhammad Damad, seorang ahli filsafat dan ilmu pasti. Sultan sendiri ikut dan terlibat dalam penelitian- penelitian ilmu ini. Selain itu 
dikembangkan pula ilmu pengetahuan agama terutama ilmu fikih, karena menurut anggapan kaum Syi'ah pintu ijtihad tidak pernah tertutup, mujtahid tidak terputus selamanya. Diantara ulama yang ternama adalah Bahau ad-Din al-Amily, dan seorang filosof Shadr al-Din asy-Syirozi. Kota Qumm dijadikan pusat kebudayaan dan penyelidikan mazhab syiah serbesar.(Sunanto, 2003: 257-258)

Pada priode Syah Abbas II kemerdekaan berpikir atau liberalitas intelektual pernah memperoleh momentumnya. Liberalitas Abbas II ditunjukkan saat memberlakukan "kebijakan toleransinya" yakni toleransi bukan hanya antar sekte Syi'ah melainkan juga toleransi antar agama. Seluruh perbedaan paham yang terdapat dalam masyarakatnya diletakkan dibawah supremasi keadilan, yang sangat bersesuaian dengan salah satu prinsip dasar dalam ajaran mazhab Syi'ah yakni prinsip al-adl.

Pada masa Abbas II ini, wanita memperolh kebebasan dalam berekpresi/ memainkan perannya dalam segala bidang termasuk dunia pendidikan. Kesejajaran para wanita pada masa ini seperti terlukiskan pada ilustrasi yang ada pada manuskrip Shahnama ( yang digambarkan sebagai puisi terpanjang yang ada sepanjang sejarah dunia kesusateraan). Dimana para wanita sengaja dilukiskan secara terpisah dengan kaum lak-laki (biasanya dipisahkan oleh gambar tenda). Pemisahan ini dapat ditafsirkan bahw apara wanita didudukkan secara setara dan diberi ruang partisipasi dalam mengelola aspek-aspek kehidupan secara sama. lingkungan sosial yang tergambarkan dalam manuskrip tersebut oleh beberapa ahli dimaknai bahwa para wanita masa Safawi memperoleh kesempatan yang sama dalam memperoleh pendidikan sains, keagamaan dan seni. (Fauzan, 2005: 143-144)

\section{KERAJAAN TURKI USMANI DI TURKI}

Ketika me-rewind jejak Turki Usmani ( Ottoman ), kita akan terbawa pada kilas balik sejarah panjang imperium Islam zaman pertengahan yang heroic sekaligus mencemaskan. Dalam catatan sejarah, sejak Usman I naik tahta secara terhormat menggantikan Alauddin (khalifah terahir Tuki Saljuk ) pada tahun 1300 M. hingga Sultan terakhir ( ke-40), Abdul Majid turun pada awal abad ke-20 (1922 ), Usmani telah memerintah selama 600 tahun.

Pada etape dua abad pertama dibawah pimpinan Sulaiman I diangkat tahun 1520, wilayah kekuasaan Turki telah sampai di semenanjung Balkan. Pasukan Turki yang secara etnografis memiliki ketangguhan dalam perang, terus melakukan ekspansi dan penyebaran Islam langsung dibawah komando Sultan. Keberhasilan menduduki Konstantinopel, symbol kekuatan terakhir imperium Romawi Timur adalah salah satu romantisme sejarah heroic yang memukau. Demikian halnya penguasaan wilayah-wilayah yang luas secara gradual, hingga Turki Utsmani menjelma menjacli raksasa yang disegani Eropa dan sekutunya.

Berikut ini wilayah-wilayah yang pernah menjadi bagian kekuasaan Turki Utsmani ( dengan masa pendudukan dan pelepasan berfariatif), yaitu Mesir, Hijaz, Yaman, Irak, Libya, Syria, Yunani, Persia, Tunisia, Palestina, Aljawir, Bulgaria, Yugoslavia, Chekoslavakia, Hongaria, Plandia, Serbia, Bosnia, Herzegovina, Albania, Rumania, dan Montenegro. (Nata, 2004: 281-282)

Dalam uraian lebih lanjut akan dikemukakan perkembangan pendidikan yang telah dilakukan oleh Sultan yang punya kepedulian yang tinggi pada pendidikan walaupun mereka lebih dikenal sebagai bangsa yang suka berperang seperti dilukiskan oleh Badri Yatim sebagai berikut : sebagai bangsa yang berdarah militer, Turki Usmani lebih banyak memfokuskan kegiatan mereka dalam bidang kemiliteran, sementara dalam bidang ilmu pengetahuan mereka kelihatan tidak keizitu menonjol. Karena itu dalam khazanah intelektual Islam kita tidak inenemukan ilmuan terkemuka dari Turki Utsmani. Namun 
demikian, mereka banyak berkiprah dalam pengembangan seni arsitektur Islam berupa bangunanbangunan Masjid yang indah, seperti masjid al-Muhammadi, atau masjid Jami' Sultan Muhammad alFatih, masjid tersebut dihiasi pula dengan kaligrafi yang indah. Salah satu masjid yang terkenal dengan keindahan kaligrafinya adalah masjid yang asalnya gereja aya Sofia. Hiasan kaligrafi itu dijadikan penutup gambar-gambar kristiani yang ada sebelumnya. (Yatim, 2003: )

Diantara Sultan yang peduli pendidikan yang tinggi antara lain Sultan Muhammad al-fatih $1481 \mathrm{M}$ / $831 \mathrm{H}$, merupakan sultan Utsmani ketujuh dalam sisilah keturunan keluarga Utsman. Muhammad digelari Al-Fatih dan Abu al-Khair, beliau adalah orang yang taqwa, wara', mencintai ilmu dan ulama, punya komitmen yang tinggi terhadap Syariat Islam, Beliau memiliki karakteristik penting yaitu : Keteguhan hati, Keberanian, Cerdas, Kemauan yang teguh dan Keadilan, Keikhlasan, dan ilmunya. (AsShalabi, 2003: 174-178). Bebrapa aksi peradabannya sebagai berikut;

\section{a. Perhatiannya terhadap akademi dan sekolah}

Perhatiannya terhadap Akademi dan Sekolah, Dia mengerahkan segenap daya upayanya untuk menyebarkan ilmu pengetahuan dan pembangunan madrasah, Beliau membangun sekolah ideal dan akademi yang menyebar di Bursah dan Adrianpole serta ditempat- tempat lainnya. Beliau memasukkan beberapa perubahan kurikulum serta berusaha mengembangkannya.

Sultan berusaha kuat menyebarkan sekolah/madrasah/ akademi di semua kota besar ataupun kecil samapi desa terpencil. Untuk itu dia mewakafkan hartanya dalam jumlah yang besar. Dia mengorganisir sekolah-sekolah dan mengaturnya dalam jenjang dan tingkatan, lalu disusunlah kurikulum, serta ditentukan pula ilmu-ilmu yang harus diajarkan di setiap level. Selain disusun system ujian untuk semua siswa.

Pendidikan diberikan scara gratis, sedangkan materi-materi yang diajarkan adalah meliputi tafsir, hadits, sastra, balagah, ilmu-ilmu ke bahasaan, arsitektur lain-lain. (As-Shalabi, 2003: 179)

Di Konstantinopel dibangun masjid dan delapan buah sekolah, di sekolah sekolah ini dibuatkan asrama dan para siswa diberikan beasiswa bulanan selama setahun penuh. Sistem yang digunakan di sekolah-sekolah Utsamni adalah system jurusan. Ilmu-ilmu yang bersangkut paut dengan ilmu-ilmu Naqliyyah ( nash ) dan teori memiliki jurusan khusus. Demikian pula halnya dengan ilmu-ilmu terapan memiliki jurusan. Para Menteri dan Ulama serta orang-orang kaya berlomba membangun akademi, sekolah-sekolah, masjid dan meberikan wakaf. (As-Shalabi, 2003: 180)

\section{b. Perhatiannya terhadap Ulama}

Para ulama dan satrawan memiliki tempat khusus dalam sanubari Sultan Muhammad al-Fatih. Dan mensejahterakan mereka walaupun dengan harta beliau sendiri. Tujuannya adalah agar seluruh potensi ulama terkonsentrasikan untuk ilmu petahuan dan mengajar. Bahkan dimana saja beliau berada selalu didampingi seorang Ulama Besar, selain sebagai guru spiritual ( penasehat, bahkan gurunya adalah seorang Tabib dan ahli kuman, Gurunya bernama Syaikh AAQ Syamsuddin, beliau telah mendefinisiakan kuman pada abad ke-15 M, saat itu belum ada mikroscop. Empat abad setelah zamannya, muncul seorang ahli kimia dan Biologi asal Peranci Louis Pasteus melakukan penelitian dengan hasil yang sama dengan yang telah ditemukan oleh Syaikh AAQ Syamsuddin. Syaikh Syamsuddin telah menulis dua buku penting Maadat al-Hayaat, dan kitab al-Thibb dua kitab ini ditulis dalam bahasa Turki dan Utsmani, selain itu menulis buku dilana bahasa Arab yaitu Hallul Musykilaat, Ar-Risalah an-Nuriyyah, Maqaaalatul Awliyaa', Risalah fi Dzikrillah, Talkhish al-Mataain, Daf ul Mataain, Risalah fi Syarh Haaji Bayaram Wali. (As-Shalabi, 2003: 144-145) 


\section{c. Perhatiannya terhadap penyair dan satrawan}

Dia memiliki 30 orang penyair kesemuanya mendapat gaji bulanan seribu disham. Maka logis jika para penyair dan sastrawan itu mengeluarkan kemampuan seninya untuk memuji Sultan atas semua penghargaannya untuk ilmu pengetahuan dan sastra.

\section{d. Perhatiannya terhadap penerjemahan}

Sangat peduli dengan penerjemahan kitab-kitab terutama khazanah lama bahasa yunani, Latin, Persia dan Arab kedalam bahasa Turki. Diantara buku diterjemahkan adalah Masyabir ar - Rijal, karya Poltark, Al-Tasbriffi fi Al-Thibbi, karaya Abu Qasim al-Zahrawi al-Andalusi, Dalam bidang geograpi dan peta dunia karya Cladius Ptolemy, Sultan mempelajarinya. Kepada para guru yang mengajar di sekolahsekolah, menjadi kewajibannya untuk menguasai buku dalam bahasa ( Arab ), seperti Ash-Shibah, AtTakmilah, Al-Qamus dan semisalnya. Di Istana beliau membangun perpustakaan khusus yang berisi ilmu-yang langka dan dia menunjuk Syaikh Luthfi untuk menjadi penjaganya. Dalam perpustakaan tersebut terdapat dua belas ribu jilid buku. Professor Dizman menyebutkan bahwa perpustakaan ini merupakan titik balik ilmu pengetahuan Timur dan barat, sayangnya terbakar pada tahun $1465 \mathrm{M}$. (AsShalabi, 2003: 184)

\section{e. Perhatiannya terhadap Pembangunan dan Rumah Sakit}

Sultan Muhammad al-Fatih membangun masjid, akademi, istana, rumah sakit, toko-toko, wc, pasar-pasar besar dan taman-taman umum. Dia membangun irigasi yakni mengalirkan air kedalam kota melalui jembatan-jembatan khusus, Dia mendorong para Menterinya, orang-orang kaya untuk membangun perumahan-perumahan, toko-toko, WC dan lain-lain yang membuat kota indah dan megah.

Pada masanya Istanbul diupayakan menjadi kota terindah di dunia, dan pusat ilmu pengetahuan dan seni. Rumah-rumah klinik menebar dimana-mana, di setiap klinik ditempatkan dua orang dokter dengan tambahan dokter spesialis di bdangnya, seperti ahli penyakit dalam, ahli bedah, ahli farmasi selain sejumlah perawat dan petugas satpam. Pengobatan di rumah sakit diberikan secara gratis kepada siapa saja tanpa melihat dari bangsa mana dan menganut agama apa. (As-Shalabi, 2003: 185)

\section{f. Perhatiannya terhadap Perdagangan dan Industri}

Beliau membangun Kota Nikaia selaku Bandar Internasional dan dilengkapi dengan infra struktur, dan sarana prasarana pendukung lainnya yang baru yang lebih baik sehingga memudahkan arus perdagangan di semua wilayah. Dampakya melahirkan kemakmuran dan kemudahan di seluruh negeri. Pemerintah Utsmani memiliki mata uang sendiri, disisi lain mereka juga bangun badan logistic, membuat senjata dan membangun benteng-benteng di tempat-tempat strategis. (As-Shalabi, 2003: 186)

\section{g. Perhatiannya terhadap masalah Administrasi}

Beliau membuat undang-undang yang disebut Qaanun Namah, yang diambil dari syari'at Islam, Undang-undang ini dijadikan sebagai asas bagi negerinya. (As-Shalabi, 2003: 187)

\section{h. Perhatiannya terhadap keamanan dan pertahanan negara}

Beliau mengatur pasukan berkuda dengan senjata lengkap, yang disesuaikan dengan penghasilan mereka, Pada setiap lima ribu Aqajah dari penghasilan mereka, maka mereka menyertakan satu pasukan kuda dan jika jumlahnya mencapai lima ratus ribu aqajah, maka wajib baginya untuk menyertakan seratus pasukan berkuda.

Pasukan Iyalat terdiri pasukan kuda dan pejalan kaki, sedangkan pasukan pejalani kaki berada dibawah komando dan kekuasaan Pasya-pasya Iyalat dan Baekawat al-Alawiyah. 
Beliau membangun industri militer guna menutupi kebutuhan pakaian pasukan, membangun tempat logistic dan gudang senjata, Melakukan pengelompokan pasukan, yang terdiri dari pasukan berkuda, pejalan kaki, pasukan pengawal meriam dan pasukan cadangan yang memberikan bantuan terhadap pasukan tempur dari apa saja yang mereka hajatkan, dari bahan baker, makanan, makanan hewan. Disana ada pasukan khusus yang bernama Algamajiah yang untuk menggali parit dibawah tanah ( terowongan ) ketika terjadi pengepungan terhadap sebuah benteng. Pada masanya telah berkembang dengan pesat akademi militer, yang dari sana menelorkan alumni para insinyur, dokter, ahli hewan, ahli ilmu alam, dan masalah ruang yang membuat pasukan Utsmani demikian terkenal di berbagai belahan dunia. Pada masanyalah kontantinopel jatuh ketangan Utsmani.

Beliau membangun armada laut dan galangan kapal yang demikian maju dalam pembuatan kapalkapal laut seperti Negara Italia, khususnya Venezia, Genoa yang merupakan Negara dengan armada terbesar di zaman itu.

Armada disebut dengan Thaaf al-'Uzb yang terdiri dari tiga ribu pasukan marinir dan terdiri dari Kapten, nakhoda kapal, pengawas dan pelaut. Beliau wafat ditengah-tengah pasukan besarnya pada tanggal 4 Rabiul awal $886 \mathrm{H}$ /,Mei $1481 \mathrm{M}$ dalam usia 52 tahun setelah berkuasa selama tiga puluh tahun lebih. (As-Shalabi, 2003: 188-206)

Setelah beliau meninggal digantikan oleh anaknya Bayazid II ( 886-918 H), Bayazid dikenal sebagai seorang Sultan yang berpenampilan tenang, mencintai sastra, sangat faqih dalam masalah syariat dan menggandrungi ilmu pengetahuan.bayazid sangat memperhatikan pembangunan sarana-sarana umum dan banyak membangun Masjid-masjid, sekolah-sekolah, rumah-rumah untuk tamu, takaya, zawiyah ( tempat berkhalwat untuk sufi). (As-Shalabi, 2003: 227)

Fazlur Rahman mengemukakan bahwa dari sudut keorganisasian, system madrasah mencapai puncaknya yang paling tinggi pada Kekaisaran Usmaniyah, sehingga madrasah-madrasah dilembagakan secara sistematik, yang langsung dipelihara dan dikelola di bawah Syaikhul Islam dengan ketrampilan dan efisiensi administrative yang sempurna. Ulama diorganisasikan dalam suatu kepangkatan dan hampir menjadi sebuah kasta dalam masyarakat Usmani. ( Rahman, 1992: 291-292)

Setelah masa Sultan Bayazid perhatian pemerintah lebih banyak ditujukan kepada penaklukan Negara-negara khususnya di Eropa, juga sebaliknya banyak mempertahankan diri melawan tentaratentara salib,maka perhatian pendidikan menjadi berkurang hingga masa Sultan Abdul Majid I ( 1854 1856 ) yang dianggap sebagai Sultan Utsmani pertama yang melakukan westernisasi pemerintahan, dan melakukan reorganisasi pemerintahan, yang intinya berkisar pada 3 masalah pokok yaitu:

a. Mengadopsi Barat dalam hal-hal yang berhubungan dengan organisasi militer dan persenjataannya serta dalam pemerintahan dan administrasinya.

b. Pembetukan orientasi sekuler di dalam pemerintahan Utsman. Usaha sentralisasi kekuasaan di Istanbul dan wilayah-wilayah. ( Rahman, 1992: 506)

Demikian gambaran pendidikan Islam pada masa turki Usmani yang dapat dikemukakan pada tulisan ini.

\section{KESIMPULAN}

Pertama, Setelah kejatuhan Bagdad. Kegiatan Ilmu yang pada masa Abbasiah berpusat di kotakota Baghdad, Bukhara, Naisabur, Ray, cordova, sevilla, ketika kota-kota tersebut hancur, maka kegiatan ilmu berpindah ke kota-kota Kairo,Iskandariyah, Usyuth, Faiyun, Damaskus,Hims, Halb dan 
lain-lain kotadi Mesir dan di Syam. Dalam masa ini, mulai matang ilmu umron ( sosiologi) dan filsafat Tarikh (philosophy of history) dengan munculnya Muqaddimah Ibnu Khaldun sebagai kitab pertama dalam bidang ini. Juga mulai disempurnakan penyusunan ilmu politik, ilmu tata usaha, ilmu peperangan, ilmu krtik sejarah. Pada masa ini sekolah-sekolah yang teratur tumbuh subur, terutama di Mesir dan Syam, dan yang menjadi pusatnya adalah Kairo dan Damaskus. Pembangun sekolah pertama adalah Sultan Nuruddin Zanky yang kemudian diikuti oleh para Raja dan Sultan sesudahnya. Berdirilah berbagai corak sekolah baik karena perbedaan Mazhab ataupun karena kekhususan Ilmu. Ada sekolah untuk ilmu tafsir dan Hadis, ada sekolah untuk Fiqh berbagai mazhab, ada sekolah untuk ilmu Thib dan filsafat, ada sekolah untuk ilmu riyad-hiya'at ( ilmu pasti, ilmu musik dan ilmu eksakta lainnya ). Dari sekolah ini keluarlah para ulama dan sarjana yang jumlahnya banyak. Keuali banyknya sekolah, zaman ini istimewa dengan lahirnya mausu'at dan majmu'at ( buku kumpulan berbagai ilmu dan masalah, kirakira seperti Encyclopedia

Kedua, Pada masa Kerajaan Mughal. Pada masa Akbar kemajuan ilmu pengetahuan tidak banyak mengalami kemajuan dibandingkan dengan kemajuannya di masa-masa sebelumnya. Yang lebih menonjol adalah kemajuan dalam bidang seni syair dan seni arsitektur. Penyair istana terkenal adalah Malik Muhammad jayazi, seorang satrawan Sufi yang menghasilakan karya besar bernama Padmavat. Ia merupakan karya Alegoris yang berisikan ajaran dan pesan kebajikan jiwa manuisa. Abul fadl merupakan sejarawan terkenal dengan karyanya Akbbar namah dan Aini Akbbari yang menerangkan sejarah Mughal berdasarkan figur Syah Jahan membangun Taj mahal untuk makam permaisuri yang sangat dicintainya. Bangunan ini menjadi kekaguman dunia sampai sekarang, termasuk salah satu dari tujuh keajaiban dunia, juga Membangun masjid Moti masjid Mutiara di Agra, disamping Taj mahal, seluruhnya terbuat dari marmer dan dipahatkan ayat al-Qur'an didalamnya dengan mempergunakan marmer hitam. Aurangzeb putera Syah jahan memerintah (1670-1707), Ia memulai jihad melawan para pemimpin Hindu dan memperluas kerajaan Mogul hingga ke India Selatan. Ia memperkenalkan kembali ortodoksi Sunni ke Masyarakat dan membangun suatu system hukum yang menyatu berdasarkan fkih mazhab Hanafi ( sebuah kompilasi besar yang berisi ajaran-ajaran mazhab ini yang diberi nama Fatawa-i Alamgiri. Pemimpinnya

Ketiga, Masa kerajaan Safawi. Pada periode Syah Abbas I merupakan puncak kejayaan Dinasti safawi. Sejarah mencatatnya sebagai bangkitnya kembali kejayaan lama Persia. Sikap Syah Abbas I terhadap pengembangan keilmuan dan pendidikan dapat dilihat dari fisik material, keberhasilannya ditunjukkan dengan dibangunnya 162 masjid dan 48 pusat pendidikan, versi lain menyebut 162 masjid dan 446 sekolah.

Ilmu pengetahuan yang berkembang pada masa ini khusus pada bidang pemikiran Teosofi dan filsafat, bukan ilmu pengetahuan dalam pengertian sains secara umum. Pemikiran teosofis dan filsuf tersebut lebih ditujukan sebagai penyatuan antara sufisme Ghnostik dengan beberapa kepercayaan Syi'i. Proses penyatuan tersebut berlangsung dalam rentang abad 16 dan 17 tersebut 


\section{Referensi}

Ali, K.(2003). Sejarah Islam Tarikh Pramodern. Jakarta : PT RajaGrafindo Persada.

As-Shalabi, Ali Muhammad. (2003). Bangkit dan runtubnya Khilafah Utsmaniyah. (terjemahan Samson Rahman ). Jakarta : Pustaka al-Kautsar.

Black, Antony. (2006). The History of Islamic Political Thouth; From the prophet to the present. diterjemahkan oleh Abdullah Ali dkk dengan judul: Pemikiran politik. Islam dari masa Nabi bingga masa kini. Jakarta :PT Serambi Ilmu Semesta.

Fauzan, Suwito \&. (2005). Sejarah Sosial Pendidikan Islam. Jakarta: Prenada media.

Lapidus, Ira M.( 2003), A History of Islamic Societis, ( terjemahan : Gufron A.Mas'udi) PT Raja Grafindo Persada.

Nata, Abuddin. (2004). Sejarah Pendidikan Islam pada priode klassik dan pertengahan. Jakarta : PT Raja Grafindo Persada.

Rahman, Fazlur. (1992). Islam, ( diterjemahkan oleh Senoaji Saleh ). Jakarta : PT Bumi Aksara.

Sirozi, M.(2005). Politik Pendidikan. Jakarta : PT RajaGrafindo Persada.

Sunanto. (2003). Musyrifah Sejarah Islam Klasik. Jakarta: Prenada media.

Yatim, Badri . (2003). Sejarah Peradaban Islam. Jakarta : PT Raja Grafindo Persada. 